Clim. Past Discuss., doi:10.5194/cp-2016-51, 2016

Manuscript under review for journal Clim. Past

Published: 18 May 2016

(c) Author(s) 2016. CC-BY 3.0 License.

Climate

of the Past

Discussions

(c) (i)

\title{
Maastrichtian carbon isotope stratigraphy and cyclostratigraphy of the Newfoundland Margin (Site U1403, IODP Leg 342)
}

Oliver Friedrich ${ }^{1}$, Sietske J. Batenburg ${ }^{2,3}$, Kazuyoshi Moriya ${ }^{4}$, Silke Voigt ${ }^{2}$, Cécile Cournède ${ }^{5}$, 5 Iris Moebius ${ }^{1,6}$, Peter Blum ${ }^{7}$, André Bornemann ${ }^{8}$, Jens Fiebig ${ }^{2}$, Takashi Hasegawa ${ }^{4}$, Pincelli M. Hull ${ }^{9}$, Richard D. Norris ${ }^{10}$, Ursula Röhl ${ }^{11}$, Thomas Westerhold ${ }^{11}$, Paul A. Wilson ${ }^{12}$ and the IODP Expedition 342 Scientists

${ }^{1}$ Institute of Earth Sciences, Ruprecht-Karls-University Heidelberg, Im Neuenheimer Feld 234-236, 69120 Heidelberg, Germany

$10{ }^{2}$ Institute of Geosciences, Goethe-University Frankfurt, Altenhöferallee 1, 60438 Frankfurt am Main, Germany

${ }^{3}$ present address: Department of Earth Sciences, University of Oxford, South Parks Road, Oxford OX1 3AN, United Kingdom

${ }^{4}$ School of Natural Sciences and Technology, Kanazawa University, Kakuma-machi, Kanazawa, Ishikawa 9201192, Japan

$15{ }^{5}$ CEREGE, Université Aix-Marseille, Europole de l'Arbois BP 80 1, 13545 Aix en Provence, France

${ }^{6}$ present address: Lamont-Doherty Earth Observatory, Columbia University, 61 Route 9W, Palisades NY 10964 , USA

${ }^{7}$ Integrated Ocean Drilling Program, Texas A\&M, 1000 Discovery Drive, College Station, TX 77845-9547, USA.

$20 \quad{ }^{8}$ Bundesanstalt für Geowissenschaften und Rohstoffe, Stilleweg 2, 30655 Hannover, Germany

${ }^{9}$ Department of Geology and Geophysics, Yale University, 210 Whitney Ave, New Haven, CT 06511, USA.

${ }^{10}$ Scripps Institution of Oceanography, University of California San Diego, 9500 Gilman Drive, La Jolla, CA 92093-0244, USA.

${ }^{11}$ MARUM, University Bremen, Leobener Strasse, 28359 Bremen, Germany

$25{ }^{12}$ National Oceanography Centre Southampton, University of Southampton, Waterfront Campus, European Way, Southampton SO14 3ZH, UK

Correspondence to: Oliver Friedrich (oliver.friedrich@geow.uni-heidelberg.de) 
Clim. Past Discuss., doi:10.5194/cp-2016-51, 2016

Manuscript under review for journal Clim. Past

Published: 18 May 2016

(c) Author(s) 2016. CC-BY 3.0 License.

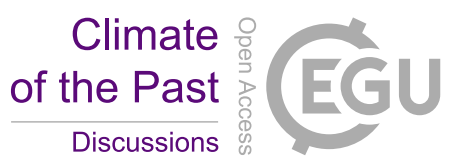

Abstract. Earth's climate during the Maastrichtian (latest Cretaceous) was punctuated by brief warming and cooling episodes, accompanied by perturbations of the global carbon cycle. Superimposed on a long-term cooling trend, the middle Maastrichtian is characterized by deep-sea warming and relatively high values of stable carbon-isotope ratios, followed by strong climatic variability towards the end of the Cretaceous. A lack of knowledge on the timing of climatic change inhibits our understanding of underlying causal mechanisms. We present an integrated stratigraphy from Site U1403, providing an expanded deep ocean record from the North Atlantic (IODP Expedition 342, Newfoundland Margin). Distinct sedimentary cyclicity suggests that orbital forcing played a major role on depositional processes, which is confirmed by statistical analyses of high resolution elemental data obtained by X-ray fluorescence (XRF) scanning. Astronomical calibration reveals that the investigated interval encompasses seven 405-kyr cycles $\left(\mathrm{Ma}_{405} 1\right.$ to $\left.\mathrm{Ma}_{405} 7\right)$ and spans $2.8 \mathrm{Myr}$ directly preceding the Cretaceous/Paleocene $(\mathrm{K} / \mathrm{Pg})$ boundary. A high-resolution carbon-isotope record from bulk carbonates allows to identify global trends in the late Maastrichtian carbon cycle. Low-amplitude variations (up to $0.4 \%$ ), typical for open ocean settings, are compared to the hemipelagic Zumaia section (N-Spain), with a well-established independent cyclostratigraphic framework. Whereas the pre-K/Pg oscillations and the negative values of the Mid-Maastrichtian Event (MME) can be readily discerned in both records, patterns diverge around 67.5 Ma, with Site U1403 more reliably reflecting global climate change. Our new carbon isotope record and the established cyclostratigraphy from Site U1403 may serve as a future reference for detailed studies of late Maastrichtian events in the North Atlantic.

\section{Introduction}

Following the high temperatures of the mid-Cretaceous greenhouse (e.g., Wilson et al., 2002; Forster et al., 2007; Bornemann et al., 2008; Friedrich et al., 2008), the latest Cretaceous is characterized by long-term climate cooling culminating in the late Campanian to Maastrichtian (e.g., Clarke and Jenkyns, 1999; Huber et al., 2002; Friedrich et al., 2012). Superimposed on this long-term trend are several short-term cooling pulses with the most pronounced episode occurring across the Campanian-Maastrichtian boundary (the so-called CampanianMaastrichtian Boundary Event, CMBE). The CMBE is characterized by distinct changes in stable oxygen and carbon isotope records, indicating deep-water cooling and changing rates of organic carbon burial (e.g., Barrera et al., 1997; Frank and Arthur, 1999; Barrera and Savin, 1999; Friedrich et al., 2004, 2009; Frank et al., 2005; Friedrich and Hemleben, 2007; Voigt et al., 2012; Jung et al., 2013). Shortly after the CMBE, the MidMaastrichtian Event (MME; MacLeod et al., 1996) marks a time of deep-sea warming (Jung et al., 2013) and the acme occurrence of inoceramid bivalves in numerous open-ocean sites (e.g., MacLeod 1994; MacLeod et al., 1996).

Although the CMBE and MME have been studied extensively (Jung et al., 2013, and references therein), the causal mechanisms triggering the events are still poorly understood due to poor constraints on timing. The low temporal resolution of Mastrichtian biozones and pronounced biotic provincialism complicate correlation further. This provincialism is related to the latest Cretaceous climate cooling which resulted in the formation of three main provinces (Tethyan, Boreal and Austral; e.g., Huber and Watkins, 1992; Premoli Silva and Sliter, 1994; Burnett, 1998; Lees, 2002; Lees and Bown, 2005). To overcome the limitations of insufficient age models and biotic provincialism, high-resolution carbon isotope curves have recently been used for detailed stratigraphic correlation of Maastrichtian sections representing a variety of depositional settings (e.g., Voigt et al., 2010, 
Clim. Past Discuss., doi:10.5194/cp-2016-51, 2016

Manuscript under review for journal Clim. Past

Published: 18 May 2016

(c) Author(s) 2016. CC-BY 3.0 License.

2012; Batenburg et al., 2012; Jung et al., 2012; Thibault et al., 2012a, b). Successful correlation of carbon isotope curves from the European shelf seas with datasets derived from deep-sea sediments in the tropical Pacific Ocean proved the usefulness and accuracy of this approach (Voigt et al., 2010, 2012). Furthermore, an astronomical age scale has been established for the Maastrichtian (Batenburg et al., 2012, 2014) that allows the reconstruction of the spatial and temporal extent of Maastrichtian events.

Here, we present a new, high-resolution carbon isotope dataset from bulk sediments of Integrated Ocean Drilling Program (IODP) Site U1403 that records carbon-cycle fluctuations in the late Maastrichtian North Atlantic off Newfoundland. Site U1403 provides an exceptional record of rhythmic and continuous sedimentation and provides the northernmost high-resolution deep-ocean record to date. Our findings show a good match between the carbon isotope dataset of Site U1403 with the high-resolution chemostratigraphic framework of the Zumaia section (northern Spain; Batenburg et al., 2012, 2014). Furthermore, an orbital timescale for the Upper Maastrichtian interval of Site U1403 based on high-resolution X-ray fluorescence (XRF) core scanning data independently supports the presented carbon isotope stratigraphy through the identification of hierarchical Milankovitch cycles. It correlates well to the available orbital age model for Zumaia (Batenburg et al., 2014).

\section{Geological setting}

Integrated Ocean Drilling Program Site U1403 $\left(39^{\circ} 56.60^{\prime} \mathrm{N}, 51^{\circ} 48.20^{\prime} \mathrm{W}\right)$ is positioned at the foot of the J Anomaly Ridge off Newfoundland (Fig. 1). It was drilled in 2012 during IODP Expedition 342 in a present-day water depth of $4949 \mathrm{~m}$ and is the deepest site that was drilled along the Newfoundland sediment drifts depth transect (Expedition 342 Scientists, 2012).

20 Maastrichtian-aged sediments at Site U1403 are nannofossil chalks that show subtle, decimeter-scale rhythmic color variations between pale yellow to very pale brown (lithological Unit Vb of Site U1403; see Expedition 342 Scientists (2012) for a detailed description of lithostratigraphic units). Calcium carbonate content of Maastrichtian sediments ranges from 35 to $80 \mathrm{wt} \%$ (Norris et al., 2014), suggesting that Site U1403 was above the CCD during the Late Cretaceous.

\section{Materials and Methods}

\subsection{Stable isotopes}

Site U1403 has been sampled at a resolution of $\sim 10 \mathrm{~cm}$ for stable carbon- and oxygen-isotope analyses on bulk carbonates (for detailed description of cores and recovery see Expedition 342 Scientists, 2012). A total of 253 samples were taken from cores 26 to 28 of Hole A and cores 28 to 32 of Hole B, spanning 247.68-296.23 m core composite depth below sea floor (CCSF; Fig. 2) After being dried and grounded, bulk samples were alternatingly analyzed using either a Finnigan MAT 253 coupled online to a Gasbench II at Goethe-University Frankfurt (Germany) or a Finnigan Delta V Advantage coupled with Gasbench II at Kanazawa-University (Japan; for details see Moriya et al., 2012). All isotope values are reported in \%o relative to the Vienna Peedee belemnite standard (VPDB). For both systems, the analytical precision of replicates of standard measurements was better than 0.06 and $0.08 \%$ for carbon and oxygen, respectively. Measuring the same samples on both machines gave no difference outside the analytical error. 
Clim. Past Discuss., doi:10.5194/cp-2016-51, 2016

Manuscript under review for journal Clim. Past

Published: 18 May 2016

(c) Author(s) 2016. CC-BY 3.0 License.

\subsection{XRF scanning}

The Maastrichtian interval of Site U1403 was analyzed by XRF scanning (X-Ray Fluorescence) on the surface of the core archive-halves in the Marum XRF Core Scanner Lab, University of Bremen, Germany. The AVAATECH instrument, serial no.11, with an Oxford Instruments $100 \mathrm{~W}$ Neptune Rh X-Ray tube and a 5 Canberra X-PIPS Silicon Drift Detector (SDD, Model SXD 15C-150-500) was set to a step-size of $15 \mathrm{~mm}$, a slit down-core of $10 \mathrm{~mm}$, and a slit cross-core of $12 \mathrm{~mm}$. A first run was applied with $10 \mathrm{kV}, 1.0 \mathrm{~mA}$, for $20 \mathrm{~s}$, and a second run at $50 \mathrm{kV}, 0.2 \mathrm{~mA}$, for $20 \mathrm{~s}$. The data were processed with WIN AXIL batch software using a $10 \mathrm{kV} \_\mathrm{Cl}-\mathrm{Rh}$ model and a $50 \mathrm{kV}$ model, respectively. Outliers, likely resulting from uneven core surfaces or micro cracks, were removed and not shown in Figure 3.

\subsection{Time series analyses and astronomical calibration}

To reduce noise, the natural logarithm of $\mathrm{Fe}$ over $\mathrm{Ca}$ was selected for further analyses (ln $\mathrm{Fe} / \mathrm{Ca}$ ), following the approach of Weltje and Tjalingii (2008), as well as the shipboard magnetic susceptibility data (WRMSL-MS, Expedition 342 scientists, 2012). The data were evenly sampled and periodicities larger than $5 \mathrm{~m}$ and $1 \mathrm{Myr}$ were removed as these periodicities are too long to be reliable detected in this dataset. A wavelet application for Matlab (Grinsted et al. 2004) was applied on the records in the depth and time domain.

In the elemental records, particularly in those of $\mathrm{Si}$ and $\mathrm{Fe}$, as well as $\ln \mathrm{Fe} / \mathrm{Ca}$, a sharp peak occurs between 265.60 and $265.85 \mathrm{~m} \mathrm{CCSF}$. Also, high variability is observed in the interval directly beneath the $\mathrm{K} / \mathrm{Pg}$ boundary. The data records were cut at these levels and spectral analyses with Redfit 3.8 (Schulz \& Mudelsee 2002) were performed on both the partial records as well as on the complete data series (Figure 5). Based on the detected spectral peaks (see Sect. 4), band-pass filters were applied using AnalySeries (Paillard et al. 1996). The filters were centered at $4.5 \mathrm{~m}$ (whole record), $4.3 \mathrm{~m}$ (upper partial record) and $3.3 \mathrm{~m}$ (lower partial record) for $\mathrm{ln}$ $\mathrm{Fe} / \mathrm{Ca}$, and at $4.4 \mathrm{~m}$ for magnetic susceptibility (whole record), with a bandwidth of approximately one third of the center frequency (Figure 4, see caption for filter details).

Consecutive minima in the $\ln \mathrm{Fe} / \mathrm{Ca}$ record that occur near minima in the band-pass filters (Figure 4) were calibrated to successive minima in the 405-kyr component of eccentricity from the new La2011 (nominal) solution (Laskar et al., 2011), based on a 405-kyr band-pass filter with a bandwidth of 300-623 kyr.

\section{Results and discussion}

\subsection{XRF scanning results and splice correction of Site U1403}

Based on the XRF scanning results, a small correction of the shipboard splice is suggested by shifting the tiepoint in Hole A, Core 27, Section 6, at $23.50 \mathrm{~cm}$ down-core by $25 \mathrm{~cm}$, from originally $259.63 \mathrm{~m}$ CCSF to 259.88 $\mathrm{m} \mathrm{CCSF}$ and adjusting all consecutive tie-points accordingly (Tab. 1). All depths bejond $259.63 \mathrm{~m}$ mentioned in the manuscript are on the revised CCSF scale. The $25 \mathrm{~cm}$ shift leads to a better matching of peaks in, among others, the Fe records of Holes A and B with high signal-to-noise-ratio in this interval but is also in agreement with the magnetic susceptibility and color reflectance data from Site U1403 which are more variable (Expedition 
Clim. Past Discuss., doi:10.5194/cp-2016-51, 2016

Manuscript under review for journal Clim. Past

Published: 18 May 2016

(c) Author(s) 2016. CC-BY 3.0 License.

The elemental records of the different elements (supplementary information and data on www.pangaea.de) can be divided in two groups. The elements $\mathrm{Al}, \mathrm{Si}, \mathrm{K}, \mathrm{Ti}, \mathrm{Mn}, \mathrm{Fe}$, and $\mathrm{Zr}$ are anticorrelated to carbonate-phase elements $\mathrm{Ca}$ and $\mathrm{Sr}$ (Fig. 3). The element $\mathrm{Ba}$ (reported as total $\mathrm{Ba}$ analyzed) displays different behavior characterized by intervals with high-frequency sharp peaks and relatively stable background values (Fig. 3 ). The elemental records show a sharp peak between 265.60 and $265.82 \mathrm{~m} \mathrm{CCSF}$, indicated by blue shading in Figure 4. This peak coincides with a marked change in the visual appearance of the cores, with closely spaced dark bands occurring below $265.60 \mathrm{~m} \mathrm{CCSF}$, and wider bands of lighter color occurring above (core images in left panel of Fig. 4). These bands occur in groups or bundles throughout the studied interval.

\subsection{Time series analyses and cyclostratigraphy}

10 The magnetic susceptibility and elemental records show variability on different spatial scales, such as a marked $\sim 20 \mathrm{~cm}$ variability in the two meters below the K/Pg boundary and a $\sim 1 \mathrm{~m}$ variability between 255 and $259 \mathrm{~m}$ $\mathrm{CCSF}$. The $\ln \mathrm{Fe} / \mathrm{Ca}$ and magnetic susceptibility datasets display many spectral peaks when the complete records are analyzed (top panels Figure 4). Main periodicities in the $\mathrm{ln} \mathrm{Fe} / \mathrm{Ca}$ record, above $99 \%$ confidence are at are at $4.5 \mathrm{~m}, 21-22 \mathrm{~cm}$ and around $17 \mathrm{~cm}$. Other prominent peaks, above $90 \%$ confidence, occur at $1.6 \mathrm{~m}, 1.1 \mathrm{~m}, 63$ $\mathrm{cm}, 46 \mathrm{~cm}, 36 \mathrm{~cm}$ and $27 \mathrm{~cm}$. For magnetic susceptibility, the main periodicities are at $4.4 \mathrm{~m}, 1.1 \mathrm{~m}, 54-60 \mathrm{~cm}$, $35 \mathrm{~cm}, 26-28 \mathrm{~cm}, 22 \mathrm{~cm}, 20 \mathrm{~cm}$ and around $17 \mathrm{~cm}$.

The partial records resulting from cutting the records at $249.56 \mathrm{~m}, 265.60 \mathrm{~m}$ and $265.85 \mathrm{~m}$ CCSF provide cleaner spectra (Fig. 5). The periodicities above $99 \%$ confidence in the upper partial record of $\ln \mathrm{Fe} / \mathrm{Ca}$ are at 44 $\mathrm{cm}, 36 \mathrm{~cm}, 26 \mathrm{~cm}, 21-22 \mathrm{~cm}$ and $16-17 \mathrm{~cm}$, and above $90 \%$ confidence periodicities of $4.2 \mathrm{~m}$ and $1.0 \mathrm{~m}$ are detected. For the upper partial record of magnetic susceptibility, main periodicities occur at $25-29 \mathrm{~cm}, 22 \mathrm{~cm}, 20$ $\mathrm{cm}$ and 16-18 cm, and other periodicities at $2.1 \mathrm{~m}, 95 \mathrm{~cm}, 43 \mathrm{~cm}$ and $36 \mathrm{~cm}$. The lower partial record of $\ln \mathrm{Fe} / \mathrm{Ca}$ has main periodicities at $22 \mathrm{~cm}$ and $15 \mathrm{~cm}$, and other prominent periodicities at $3.3 \mathrm{~m}$ and $17 \mathrm{~cm}$. The lower partial record of magnetic susceptibility shows dominant periodicities around $20-22 \mathrm{~cm}$, and other prominent periodicities at $3 \mathrm{~m}, 53-64 \mathrm{~cm}$ and $35 \mathrm{~cm}$. For completeness, also the spectral analyses of the records only cut at 249.56 are displayed (Figure 5, lower panels).

The strong periodicities in the upper part of the $\ln \mathrm{Fe} / \mathrm{Ca}$ and magnetic susceptibility records, at $4.2 \mathrm{~m}$, at $1 \mathrm{~m}$, at 44 and $36 \mathrm{~cm}$ and at $21-22 \mathrm{~cm}$, have a ratio near that of the main periodicities of the orbital parameters of eccentricity-modulated precession and obliquity (20:5:2:1, formed by the ratio of the $405 \mathrm{kyr}, 100 \mathrm{kyr}, 41 \mathrm{kyr}$ and $22 \mathrm{kyr}$ components). The same holds true for the lower part of the record, with periodicities at 3.3 and $3.0 \mathrm{~m}$,

$3064 \mathrm{~cm}, 22 \mathrm{~cm}$ and $15 \mathrm{~cm}$, albeit less clear due to the shorter length of the partial record. The shift in periodicities is likely caused by an increase in sedimentation rate at $265.60 \mathrm{~m} \mathrm{CCSF}$, which is supported by the changes in the spacing of dark bands (Fig. 4).

During overall maxima of $\mathrm{Fe}$ and minima of $\mathrm{Ca}$ and corresponding maxima of $\mathrm{ln} \mathrm{Fe} / \mathrm{Ca}$, the respective elemental intensity records as well as the $\mathrm{ln} \mathrm{Fe} / \mathrm{Ca}$ record display maximal variability (Fig. 4). This pattern likely reflects the sedimentary response to eccentricity-modulated precession, with high variability caused by large amplitude of the precessional forcing during eccentricity maxima. The observed rhythmic pattern displays the combined influence of variations in three main driving factors: carbonate productivity; dilution of carbonate content by siliciclastic terrigenous input; and the potential effect of local dissolution. Maxima in Fe counts coincide with minima in $\mathrm{Ca}$ counts (high $\ln \mathrm{Fe} / \mathrm{Ca}$ ) and can be interpreted to reflect increasing terrigenous input, decreased carbonate production and/or increased dissolution or a combination of all. We hypothesize that our data reflect 
Clim. Past Discuss., doi:10.5194/cp-2016-51, 2016

Manuscript under review for journal Clim. Past

Published: 18 May 2016

(c) Author(s) 2016. CC-BY 3.0 License.

highest terrigenous input and/or lowest carbonate production in times of maximal eccentricity. Increased terrigenous input during eccentricity maxima may indicate more runoff potentially caused by an intensified hydrological cycle whereas the increase in variability reflects the increasing influence of precessional forcing on the hydrological regime. In this scenario, minima of $\mathrm{Ca}$ would primarily reflect dilution by terrigenous material. The dark bands directly observed below the K/Pg boundary (see core pictures in Fig. 4) may reflect local shortlived dissolution events that led to additional Fe enrichment and Ca depletion.

Based on the above-mentioned sedimentary response to eccentricity-modulated precession, minima in the $\ln$ $\mathrm{Fe} / \mathrm{Ca}$ record that occur near minima in the $4.5 \mathrm{~m}, 4.4 \mathrm{~m}$ and $3.3 \mathrm{~m}$ band-pass filters are assigned the ages of minima in the 405-kyr component of eccentricity from the La2011 solution (Laskar et al, 2011) (Tab. 2). This interpretation is supported by the occurrence of increased amplitude of $36-46 \mathrm{~cm}$ periodicities at five such levels, which likely corresponds to more prominent obliquity forcing during 405-kyr eccentricity minima. Astronomic calibration uses the $\mathrm{K} / \mathrm{Pg}$ boundary as starting point with an age of $66.04 \mathrm{Ma}$ based on new bentonite ages from coals near the K/Pg boundary of 66.04 Ma (Renne et al., 2013). After assigning ages to the consecutive 405-kyr minima, the main periodicities of the calibrated ln Fe/Ca record are at 404, 143, 24 and $22 \mathrm{kyr}$ (above 99\% confidence), with other periodicities (above 90\% confidence) at 96, 85, 51 and 38 kyr. For the calibrated magnetic susceptibility record, main periodicities are at 417, 85, 46, 34, 24 and $19 \mathrm{kyr}$, with other periodicities at 143 and 97 kyr (Fig. 6). These periodicities broadly correspond to the periodicities of obliquity and eccentricitymodulated precession, and display a regular behavior throughout the record (wavelet panels, Fig. 6).

The investigated interval of Site U1403 encompasses seven 405-kyr cycles $\left(\mathrm{Ma}_{405} 1\right.$ to $\mathrm{Ma}_{405} 7$, Husson et al., 2011 following the nomenclature of Westerhold et al., 2008; Fig. 6) in total and spans 2.8 Myr (68.8 to 66.04 Ma). This highlights the potential of Site U1403 to serve as a latest Maastrichtian reference section in the Atlantic Ocean. It provides the possibility to investigate the timing and duration of underlying causes and trigger mechanisms of climatic and oceanographic events and fluctuations like the MME or the K/Pg boundary as well as the time interval in-between. Especially, Site U1403 is located within the pathway of a potential Northern Component water mass which is suggested to have been a source of deep water in the North Atlantic Ocean (e.g., MacLeod et al., 2011; Robinson and Vance, 2012; Voigt et al., 2013).

\subsection{Stable oxygen isotope signal}

Carbonates of the studied nannofossil oozes consist mainly of coccoliths and benthic and planktic foraminifera (Expedition 342 Scientists, 2012). Bulk oxygen isotope values therefore predominantly represent a surface-water signal. The $\delta^{18} \mathrm{O}$-composition of bulk carbonate can be significantly altered by diagenetic processes like lowtemperature exchange with pore fluids or burial diagenesis (e.g., Marshall, 1992; Schrag et al., 1995). Therefore, we refrain from calculating absolute temperatures based on oxygen isotope values. Variations in bulk oxygen isotope records, however, are often considered to reflect relative changes in temperature (e.g., Jenkyns et al., 1994; Voigt and Wiese, 2000; Friedrich et al., 2003; Kuhnt et al., 2011).

35 The bulk carbonate oxygen isotope record from Site U1403 is characterized by relatively stable values between 253 and $275 \mathrm{~m} \mathrm{CCSF}$ which vary between 0 and $-0.6 \%$ (Fig. 2). Above $253 \mathrm{~m} \mathrm{CCSF}, \delta^{18} \mathrm{O}$ values decrease slightly, followed by a pronounced negative excursion between 249 and $248 \mathrm{~m}$ CCSF with minimum values of $1.5 \%$ within nannofossil zone UC20d (Fig. 2). This decrease in oxygen isotope values suggests a significant increase in surface-water temperatures directly preceding the $\mathrm{K} / \mathrm{Pg}$ boundary, as has been described in previous studies (e.g., Barrera, 1994; Li and Keller, 1998). 
Clim. Past Discuss., doi:10.5194/cp-2016-51, 2016

Manuscript under review for journal Clim. Past

Published: 18 May 2016

(c) Author(s) 2016. CC-BY 3.0 License.

4.4 Carbon isotope stratigraphy and comparison to the Zumaia record

Carbon isotope values of carbonates are less prone to diagenetic alterations than oxygen isotope values (e.g., Anderson and Arthur, 1983; Marshall, 1992) and are a reliable recorder of changes in the global carbon cycle (e.g., Weissert et al., 2008). Especially for pelagic carbonate successions the method of carbon isotope stratigraphy has been successfully applied for stratigraphic correlation on a global scale and across different depositional settings (e.g., Voigt et al., 2010, 2012; Batenburg et al., 2012; Jung et al., 2012; Thibault et al., 2012a, b).

The bulk carbon isotope record of Site U1403 shows variability on long and short timescales. While $\delta^{13} \mathrm{C}$ values increase in the lower half of the record (275 to $260 \mathrm{~m} \mathrm{CCSF}$, Fig. 2) to maximum values of $3.15 \%$, they decrease towards the top of the studied interval, resulting in minimum values of $2.3 \%$.

The pattern of $\delta^{13} \mathrm{C}$ values found in Site U1403 can be compared to the trends in bulk carbonate $\delta^{13} \mathrm{C}$ values from the Zumaia section in northern Spain (Batenburg et al., 2012), which has an independent astrochronology (Fig. 7). For the Zumaia succession, rhythmic lithological alternations form the basis of a cyclostratigraphic framework, tested by statistical analyses of high-resolution magnetic susceptibility and color reflectance data. A 405-kyr band-pass filter of magnetic susceptibility is displayed at the right hand side of Figure 7. Compared to the carbon isotope data of Site U1403, the Zumaia record shows variations with a larger amplitude (up to $1 \%$; Fig. 7). This reflects the influence of regional processes such as weathering, runoff and productivity, which may have changed the carbon inventory of the relatively restricted Basque-Cantabric basin, and caused short-term variations superimposed on long-term global trends. The relatively low amplitude variations of bulk carbon isotope values from Site U1403 (up to $0.4 \%$; Figs 2, 7) are typical for open ocean settings like the Tethys (Voigt et al., 2012; Sprovieri et al., 2013), the tropical Pacific (Sites 305 and 1210; Voigt et al., 2010; Jung et al., 2012) or the Indian Ocean (Site 762; Thibault et al., 2012a).

Both carbon isotope records show an overall decreasing trend through the late Maastrichtian. Markedly negative values near the base of the U1403 record coincide with the Mid-Maastrichtian Event at 68.6 Ma. Distinct oscillations can be observed in both records over a million-year interval prior to the $\mathrm{K} / \mathrm{Pg}$ boundary. In between these coeval shifts, the Zumaia record displays a negative shift around 67.5 Ma, which may be related to a relative drop in sea level (Batenburg et al., 2012). The behavior of the carbon isotope record of Site U1403 is likely more representative of changes in the global carbon cycle. This interpretation is supported by a comparison of available nannofossil marker species. At Site U1403, shipboard calcareous nannofossil biostratigraphy indicates zones UC20b to UC20d (Norris et al., 2014). Boundaries between these zones are at $\sim 66.68 \mathrm{Ma}$ (base Ceratolithoides kamptneri) and $\sim 66.47 \mathrm{Ma}$ (base Micula prinsii) if the herein established age model is applied. These estimated ages are somewhat older than compared to the same events at Zumaia (Batenburg et al., 2014). However, diachroneity has been noted in M. prinsii, with later Boreal appearances (see Gradstein et al., 2012, notes). At ODP Site 762C, Thibault et al. (2012a) reported Base M. prinsii towards the base of 29r (66.39 Ma) and Thibault et al. (2015) report a range of $M$. prinsii ages from 66.2-67 Ma, but mostly towards the younger end of the range, which is generally in good agreement with the estimated age of this study. Although Site U1403 and the Zumaia section represent completely different depositional settings, the carbon isotope curves display similar broad trends when presented on independent age models. Differences between the curves can be used to identify global versus regional controls on recorded $\delta^{13} \mathrm{C}$. This highlights the usefulness of 
Clim. Past Discuss., doi:10.5194/cp-2016-51, 2016

Manuscript under review for journal Clim. Past

Published: 18 May 2016

(c) Author(s) 2016. CC-BY 3.0 License.

carbon isotopes for stratigraphic purposes in the latest Cretaceous and their potential to unravel the underlying causes and trigger mechanisms of paleoclimatic and paleoceanographic events.

\section{Conclusions}

Based on our high-resolution XRF core scanning data, we identify a small correction of the shipboard splice and establish an orbital chronology for the late Maastrichtian interval of Site U1403. The investigated interval encompasses seven 405-kyr cycles $\left(\mathrm{Ma}_{405} 1\right.$ to $\left.\mathrm{Ma}_{405} 7\right)$, spanning 2.8 Myr from 68.8 to 66.0 Ma. Our new highresolution stable carbon isotope record from Site U1403 (IODP Expedition 342, Newfoundland Margin) shows distinct variations, including the Mid-Maastrichtian Event and the oscillations prior to the K/Pg boundary. These trends can be correlated to carbon isotope records elsewhere, e.g. the Zumaia section in northern Spain. Comparison of carbon isotope stratigraphies from open-ocean and shelf settings not only provides a dating tool, but also adds insights in regional versus global drivers of the Earth's carbon cycle. Amplitudes of the carbon isotope variations at Zumaia are significantly higher than at U1403, indicating a strong influence of regional processes in the narrow Basque-Cantabric basin on the carbon isotope signal. The U1403 record displays typical open ocean values when compared to other records. In the future, Site U1403 might serve as a potential reference section for paleoclimatic and paleoceanographic events and fluctuations during the latest Cretaceous.

Acknowledgements. This research used samples provided by the Integrated Ocean Drilling Program (IODP), which is sponsored by the U.S. National Science Foundation and participating countries under management of Joint Oceanographic Institutions, Inc. This research used data acquired at the XRF Core Scanner Lab at the MARUM - Center for Marine Environmental Sciences, University of Bremen, Germany. Sven Hofmann is thanked for laboratory assistance. Dominik Leonhardt helped with processing of sediment samples. Funding for this study was provided by the DFG to O.F. (Emmy Noether research group "Meso- and Cenozoic paleoceanography"; grant FR2544/2-1 and grant FR2544/5) and to S.V. (DFG grant VO 687/14-1).

\section{References}

Anderson, T. F., and Arthur, M. A.: Stable isotopes of oxygen and carbon and their application to sedimentologic and paleoenvironmental problems. In: Arthur, M. A., Anderson, T. F., Kaplan, I. R. V. J., Land, L. S. (Eds.): Stable Isotopes in Sedimentary Geology. Society of Economic Paleontologists and Mineralogists, Dallas, pp. 1-151. 1983.

Barrera, E.: Global environmental changes preceding the Cretaceous-Tertiary boundary: Early-Late Maastrichtian transition, Geology, 22, 877-880, 1994.

Barrera, E., and Savin, S. M.: Evolution of late Campanian-Maastrichtian marine climates and oceans, Spec. Pap. Geol. Soc. Am., 332, 245-282, 1999.

Barrera, E., Savin, S. E., Thomas, E., and Jones, C. E.: Evidence for thermohaline-circulation reversals controlled by sea-level change in the latest Cretaceous, Geology, 25, 715-718, 1997.

Batenburg, S. J., Sprovieri, M., Gale, A. S., Hilgen, F. J., Hüsing, S., Laskar, J., Liebrand, D., Lirer, F., OrueEtxebarria, X., Pelosi, N., and Smit, J.: Cyclostratigraphy and astronomical tuning of the Late Maastrichtian at Zumaia (Basque country, Northern Spain), Earth Planet. Sci. Let., 359-360, 264-278, 
Clim. Past Discuss., doi:10.5194/cp-2016-51, 2016

Manuscript under review for journal Clim. Past

Published: 18 May 2016

(c) Author(s) 2016. CC-BY 3.0 License.

2012.

Batenburg, S. J., Gale, A. S., Sprovieri, M., Hilgen, F. J., Thibault, N., Boussaha, M., and Orue-Etxebarria, X.: An astronomical time scale for the Maastrichtian based on the Zumaia and Sopelana sections (Basque country, northern Spain), J. Geol. Soc., 171, 165-180, 2014.

Bornemann, A., Norris, R. D.,Friedrich, O., Beckmann, B., Schouten, S., Sinninghe Damsté, J. Vogel, J., Hofmann, P., and Wagner, T.: Isotopic evidence for glaciation during the Cretaceous supergreenhouse, Science, 319 , 189-192, 2008.

Burnett, J. A.: Upper Cretaceous, in Calcareous nannofossil biostratigraphy. In: Bown, P.R. (Eds.). Chapman and Hall, London, pp. 132-199, 1998.

Clarke, L. J., and Jenkyns, H. C.: New oxygen-isotope evidence for long-term Cretaceous climate change in the Southern Hemisphere, Geology, 27, 699-702, 1999.

Expedition 342 Scientists 2012.: Paleogene Newfoundland sediment drifts. IODP Prel. Rept., 342. doi:10.2204/iodp.pr.342.2012, 2012.

Forster, A., Schouten, S., Baas, M., and Sinninghe Damsté, J.: Mid-Cretaceous (Albian-Santonian) sea surface temperature record of the tropical Atlantic Ocean, Geology, 35, 919-922, 2007.

Frank, T. D., and Arthur, M. A.: Tectonic Forcings of Maastrichtian Ocean-Climate Evolution, Paleoceanography, 14, 103-117, 1999.

Frank, T.D., Thomas, D.J., Leckie, R.M., Arthur, M.A., Bown, P.R., Jones, K., and Lees, J.A.: The Maastrichtian record from Shatsky Rise (northwest Pacific): A tropical perspective on global ecological and oceanographic changes, Paleoceanography, 20, doi:10.1029/2004PA001052, 2005.

Friedrich, O., and Hemleben, C.: Early Maastrichtian benthic foraminiferal assemblages from the western North Atlantic (Blake Nose) and their relation to paleoenvironmental changes, Mar. Micropaleontol., 62, 31-44, 2007.

Friedrich, O., Reichelt, K., Herrle, J.O., Lehmann, J., Pross, J., and Hemleben, C.: Formation of the Late Aptian Niveau Fallot black shales in the Vocontian Basin (SE France): evidence from foraminifera, palynomorphs, and stable isotopes. Mar. Micropaleontol., 49, 65-85, 2003.

Friedrich, O., Herrle, J. O., Kößler, P., and Hemleben, C.: Early Maastrichtian stable isotopes: changing deep water sources in the North Atlantic?, Palaeogeogr. Palaeoclimatol Palaeoecol., 211, 171-184, 2004.

Friedrich, O., Erbacher, J., Moriya, K., Wilson, P. A., and Kuhnert, H.: Warm saline intermediate waters in the Cretaceous tropical Atlantic Ocean, Nature Geosci., 1, 453-457, 2008.

Friedrich, O., Herrle, J. O., Wilson, P. A., Cooper, M. J., Erbacher, J., and Hemleben, C.: Early Maastrichtian carbon cycle perturbation and cooling event: Implications from the South Atlantic Ocean, Paleoceanography, 24, PA2211, doi: 10.1029/2008PA001654, 2009.

Friedrich, O., Norris, R. D., and Erbacher, J.: Evolution of middle to Late Cretaceous oceans-A 55 m.y. record of Earth's temperature and carbon cycle, Geology, 40, 107-110, 2012.

Gradstein, F. M., Ogg, J. G., Schmitz, M. D., and Ogg, G. M. (coordinators): The Geologic Time Scale 2012. Boston, USA: Elsevier, 2 volumes plus chart, 1176 pp., 2012.

Grinsted, A., Moore, J. C., and Jevrejeva, S.: Application of the cross wavelet transform and wavelet coherence to geophysical time series, Nonlinear Processes in Geophysics, 11, 561-566, 2004. 
Clim. Past Discuss., doi:10.5194/cp-2016-51, 2016

Manuscript under review for journal Clim. Past

Published: 18 May 2016

(c) Author(s) 2016. CC-BY 3.0 License.

Huber, B. T., and Watkins, D. K.: Biogeography of Campanian-Maastrichtian calcareous plankton in the region of the Southern Ocean: paleogeographic and paleoclimatic implications, Antarct. Res. Ser., 56, 31-60, 1992.

Huber, B. T., Norris, R. D., and MacLeod, K. G.: Deep-sea paleotemperature record of extreme warmth during the Cretaceous, Geology, 30, 123-126, 2002.

Husson, D., Galbrun, B., Laskar, J., Hinnov, L.A., Thibault, N., Gardin, S., and Locklair, R.E.: Astronomical calibration of the Maastrictian (Late Cretaceous), Earth Planet. Sci. Let., 305, 328-340, 2011.

Jenkyns, H.C., Gale, A.S., and Corfield, R.M.: Carbon- isotope and oxygen- isotope stratigraphy of the English Chalk and Italian Scaglia and its palaeoclimatic significance, Geol. Mag., 131, 1-34, 1994.

Jung, C., Voigt, S., and Friedrich, O.: High-resolution carbon-isotope stratigraphy across the CampanianMaastrichtian boundary at Shatsky Rise (tropical Pacific), Cret. Res., 37, 177-185, 2012.

Jung, C., Voigt, S., Friedrich, O., Koch, M.C., and Frank, M.: Campanian-Maastrichtian ocean circulation in the tropical Pacific, Paleoceanography, 28, 562-573, 2013.

Kuhnt, W., Holbourn, A., and Moullade, M.: Transient global cooling at the onset of early Aptian oceanic anoxic event (OAE) 1a, Geology, 39, 323-326, 2011.

Kuiper, K. F., Deino, A., Hilgen, F. J., Krijgsman, W., Renne, P. R., and Wijbrans J. R.: Synchronizing Rock Clocks of Earth History, Science, 320, 500-504, 2008.

Laskar, J., Gastineau, M., Delisle, J.-B., Farrés, A., and Fienga, A.: Strong chaos induced by close encounters with Ceres and Vesta, Astronomy and Astrophys., 532, L4, 2011.

Lees, J.A.: Calcareous nannofossil biogeography illustrates palaeoclimate change in the Late Cretaceous Indian Ocean, Cret. Res., 23, 537-634, 2002.

Lees, J.A., and Bown, P.R.: Upper Cretaceous calcareous nannofossil biostratigraphy, ODP Leg 198 (Shatsky Rise, northwest Pacific Ocean), Proc. ODP, 198, 1-60, 2005.

Li, L., and Keller, G.: Maastrichtian climate, productivity and fauna1 turnovers in planktic foraminifera in South Atlantic DSDP sites 525A and 21, Mar. Micropaleontol., 33, 55-86, 1998.

MacLeod, K.G.: Bioturbation, inoceramid extinction and mid Maastrichtian ecological change, Geology, 22, 139-142, 1994.

MacLeod, K. G., Huber, B. T., and Ward, P. D.: The biostratigraphy and paleobiogeography of Maastrichtian inoceramids, Spec. Pap. Geol. Soc. Am., 307, 361-373, 1996.

MacLeod, K. G., Londono, C. I., Martin, E. E., Berrocoso, A. J., and Basak, C.: Changes in North Atlantic circulation at the end of the Cretaceous greenhouse interval, Nature Geosci., 4, 779-782, 2011.

Marshall, J. D.: Climatic and oceanographic isotopic signals from the carbonate rock record and their preservation, Geol. Mag., 129, 143-160, 1992.

Moriya, K., Goto, A. S., and Hasegawa, T.: Stable carbon and oxygen isotope analyses of carbonate using a continuous flow isotope ratio mass spectrometry. The science reports of the Kanazawa University, 56, 45$58,2012$.

Norris, R.D., Wilson, P.A, Blum, P., and the Expedition 342 Scientists: Proc. IODP, 342, College

Station, TX (Integrated Ocean Drilling Program), doi:10.2204/iodp.proc.342.2014, 2014.

Paillard, D., Labeyrie, L., and Yiou, P.: Macintosh program performs timeseries analysis. EOS Transactions, 77, 
Clim. Past Discuss., doi:10.5194/cp-2016-51, 2016

Manuscript under review for journal Clim. Past

Published: 18 May 2016

(c) Author(s) 2016. CC-BY 3.0 License.

Premoli Silva, I., and Sliter, W. V.: Cretaceous planktonic foraminiferal stratigraphy and evolutionary trends from the Bottacione section, Gubbio, Italy, Paleontogr. Ital., 82, 1-89, 1994.

Renne, P. R., Deino, A. L., Hilgen, F. J., Kuiper, K. F., Mark, D. F., Mitchell, W. S., Morgan, L. E., Mundil, R., and Smit, J.: Time scale of critical events around the Cretaceous-Paleogene boundary, Science, 339, 684687, 2013.

Robinson, S. A., and Vance, D.: Widespread and synchronous change in deep-ocean circulation in the North and South Atlantic during the Late Cretaceous, Paleoceanography, 27, PA1102, doi:10.1029/2011PA002240, 2012.

Schrag, D. P., DePaolo, D. J., and Richter, F. M.: Reconstructing past sea surface temperatures: Correcting for diagenesis of bulk marine carbonate, Geochim. Cosmochim. Acta, 59, 2265-2278, 1995.

Schulz, M., and Mudelsee, M.: REDFIT: estimating red-noise spectra directly from unevenly spaced paleoclimatic time series, Comp. Geosci., 28, 421-426, 2002.

Sprovieri, M., Sabatino, N.; Pelosi, N., Batenburg, S.J., Coccioni, R., Iavarone, M., and Mazzola, S.: Late Cretaceous orbitally-paced carbon isotope stratigraphy from the Bottaccione Gorge (Italy), Palaeogeogr. Palaeoclimatol. Palaeoecol., 379, 81-94, 2013.

Thibault, N., Husson, D., Harlou, R., Gardin, S., Galbrun, B., Huret, E., and Minoletti, F.: Astronomical calibration of upper Campanian-Maastrichtian carbon isotope events and calcareous plankton biostratigraphy in the Indian Ocean (ODP Hole 762C): Implication for the age of the CampanianMaastrichtian boundary, Palaeogeogr. Palaeoclimatol. Palaeoecol., 337-338, 52-71, 2012a.

Thibault, N., Harlou, R., Schovsbo, N., Schioler, P., Lauridsen, B. W., Sheldon, E., Stemmerik, L., and Surlyk, F.: Upper Campanian - Maastrichtian carbon-isotope stratigraphy of the Danish Basin: calibration with calcareous nannofossil and dinoflagellate events in the Boreal Realm, Cret. Res., 33, 72-90, 2012b.

Thibault, N., Anderskouv, K., Bjerager, M., Boldreel, L. O., Jelby, M. E., Stemmerik, L., and Surlyk, F.: Upper Campanian-Maastrichtian chronostratigraphy of the Skaelskor-1 core, Denmark: correlation at the basinal and global scale and implications for changes in sea-surface temperatures, Lethaia, 48, 549-560, 2015.

Voigt, S., and Wiese, F.: Evidence for Late Cretaceous (late Turonian) climate cooling from oxygen-isotope variations and palaeobiogeographic changes in Western and Central Europe, J. Geol. Soc., 157, 737-744, 2000.

Voigt, S., Friedrich, O., Norris, R. D., and Schönfeld, J.: Campanian - Maastrichtian carbon isotope stratigraphy: shelf-ocean correlation between the European shelf sea and the tropical Pacific Ocean, Newsl. Stratigr., 44, 57-72, 2010.

Voigt, S., Gale, A. S., Jung, C., and Jenkyns, H. C.: Global correlation of Upper Campanian - Maastrichtian successions using carbon-isotope stratigraphy: development of a new Maastrichtian timescale, Newsl. Stratigr., 45, 25-53, 2012.

Voigt, S., Jung, C., Friedrich, O., Frank, M., Teschner, C., and Hoffmann, J.: Tectonically restricted deep-ocean circulation at the end of the Cretaceous greenhouse, Earth Planet. Sci. Let., 369-370, 169-177, 2013.

Weissert, H., Joachimski, J., and Sarnthein, M.: Chemostratigraphy. Newsl. Stratigr., 42, 145-179, 2008.

Weltje, G. J., and Tjallingii, R.: Calibration of XRF core scanners for quantitative geochemical logging of sediment cores: theory and application, Earth Planet. Sci. Let., 274, 423-438, 2008.

40 Westerhold, T., Röhl, U., Raffi, I., Fornaciari, E.,Monechi, S., Reale, V., Bowles, J., Evans, H.F.: Astronomical 
Clim. Past Discuss., doi:10.5194/cp-2016-51, 2016

Manuscript under review for journal Clim. Past

Published: 18 May 2016

(c) Author(s) 2016. CC-BY 3.0 License.

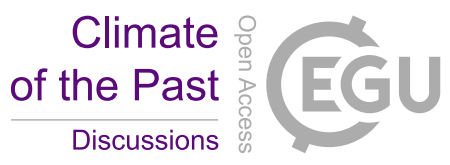

(c) (i)

calibration of the Paleocene time. Palaeogeogr. Palaeoclimatol. Palaeoecol., 257, 377-403, 2008.

Wilson, P. A., Norris, R. D., and Cooper, M. J.: Testing the Cretaceous greenhouse hypothesis using glassy foraminiferal calcite from the core of the Turonian tropics on Demerara Rise, Geology, 30, 607-610, 2002. 
Clim. Past Discuss., doi:10.5194/cp-2016-51, 2016

Manuscript under review for journal Clim. Past

Published: 18 May 2016

(c) Author(s) 2016. CC-BY 3.0 License.

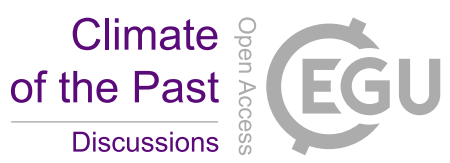

(c) (1)

Table 1: Adjusted splice table for the Maastrichtian interval of Site U1403. A $25 \mathrm{~cm}$ shift is applied to the shaded values.

$\begin{array}{llllllllllllll}\text { Hole } & \text { Core } & \text { Sect. } & \text { Level }(\mathrm{cm}) & \text { m CSF-A } & \text { m CCSF } & & & \text { Hole } & \text { Core } & \text { Sect. Level }(\mathrm{cm}) & \text { m CSF-A } & \text { m CCSF } \\ \text { A } & 27 & 6 & 48.50 & 232.19 & 259.88 & \text { TIE } & \text { B } & 29 & 1 & 91 & 227.21 & 259.88 \\ \text { B } & 29 & 5 & 91.00 & 232.96 & 265.63 & \text { TIE } & \text { A } & 28 & 2 & 119.4 & 236.594 & 265.63 \\ \text { A } & 28 & 5 & 134.30 & 240.993 & 270.03 & \text { TIE } & \text { B } & 30 & 1 & 89 & 236.89 & 270.03 \\ \text { B } & 30 & 4 & 115.00 & 241.4 & 274.54 & \text { APPEND } & \text { B } & 31 & 1 & 2.5 & 245.725 & 279.84 \\ \text { B } & 31 & \text { CC } & 71.30 & 251.873 & 285.98 & \text { APPEND } & \text { B } & 32 & 1 & 2.5 & 255.425 & 290.51 \\ \text { B } & 32 & 5 & 88.60 & 261.736 & 296.82 & & & & & & & & \end{array}$


Clim. Past Discuss., doi:10.5194/cp-2016-51, 2016

Manuscript under review for journal Clim. Past

Published: 18 May 2016

(c) Author(s) 2016. CC-BY 3.0 License. \begin{aligned} Climate \\ of the Past \\ \hline Discussions \end{aligned} (c)

Table 2: Tie-points for reconstructing the age model and resulting linear sedimentation rates.

$\begin{array}{lll}\begin{array}{l}\text { Depth med } \\ \text { (CCSF-A) }\end{array} & \text { Age (Ma) } & \begin{array}{l}\text { Sed. Rate } \\ \text { (cm/kyr) }\end{array} \\ 247.700 & 66.04 & \\ 251.040 & 66.374 & 1.00 \\ 254.960 & 66.782 & 0.96 \\ 259.205 & 67.192 & 1.04 \\ 263.695 & 67.585 & 1.14 \\ 268.365 & 67.986 & 1.16 \\ 271.680 & 68.383 & 0.84 \\ 274.635 & 68.787 & 0.73 \\ 275.000 & 68.837 & 0.73\end{array}$


Clim. Past Discuss., doi:10.5194/cp-2016-51, 2016

Manuscript under review for journal Clim. Past

Published: 18 May 2016

(c) Author(s) 2016. CC-BY 3.0 License.

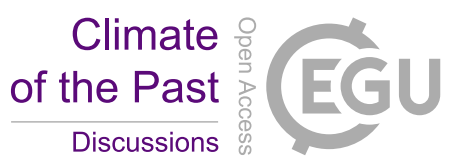

(c) (i)

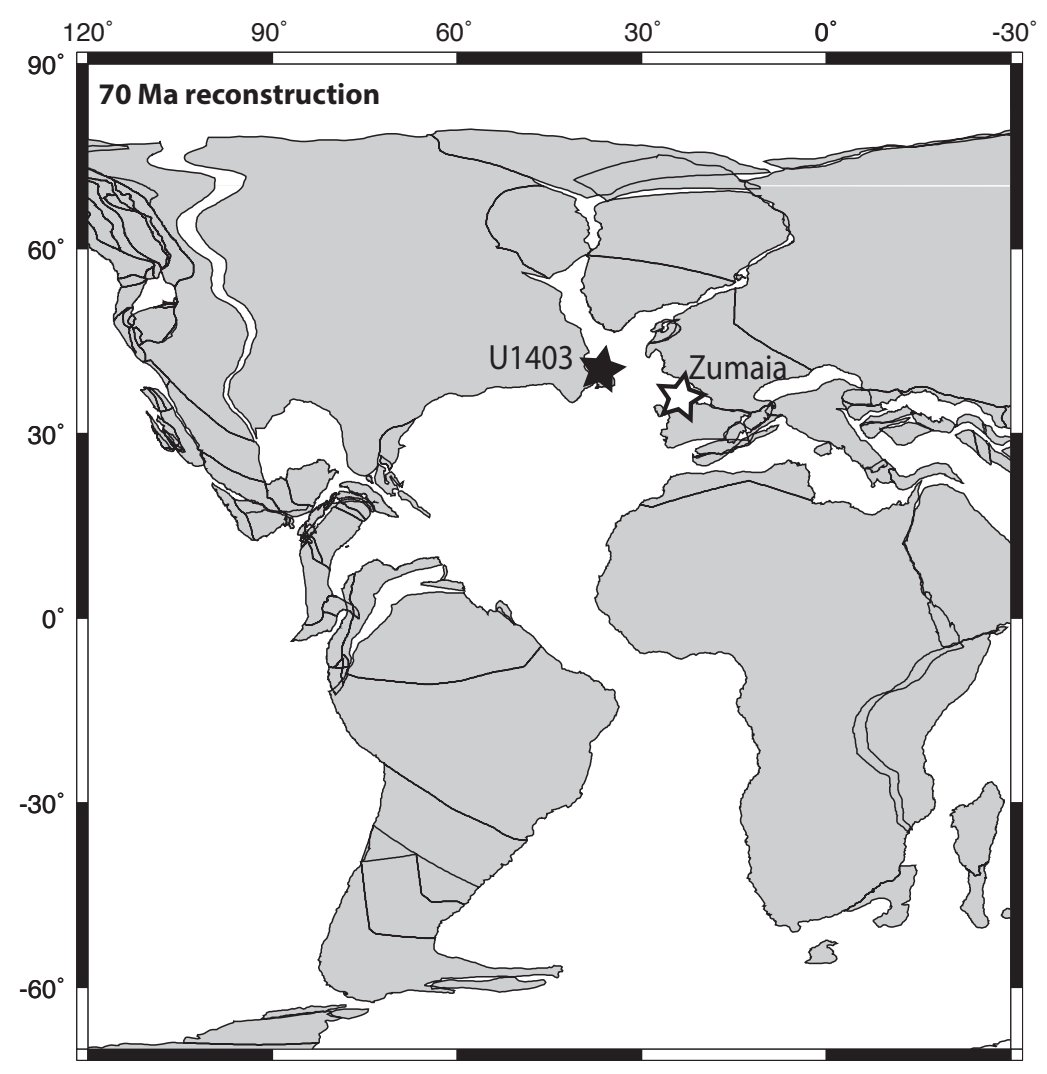

Figure 1: Paleogeographic reconstruction for the Maastrichtian (70 Ma reconstruction based on www.odsn.de; Hay et al., 1999) showing locations of sites discussed (Site U1403, this study, black star; Zumaia section, white star). 
Clim. Past Discuss., doi:10.5194/cp-2016-51, 2016

Manuscript under review for journal Clim. Past

Published: 18 May 2016

(c) Author(s) 2016. CC-BY 3.0 License. \begin{aligned} Climate \\ of the Past \\ \hline Discussions \end{aligned}

(c)

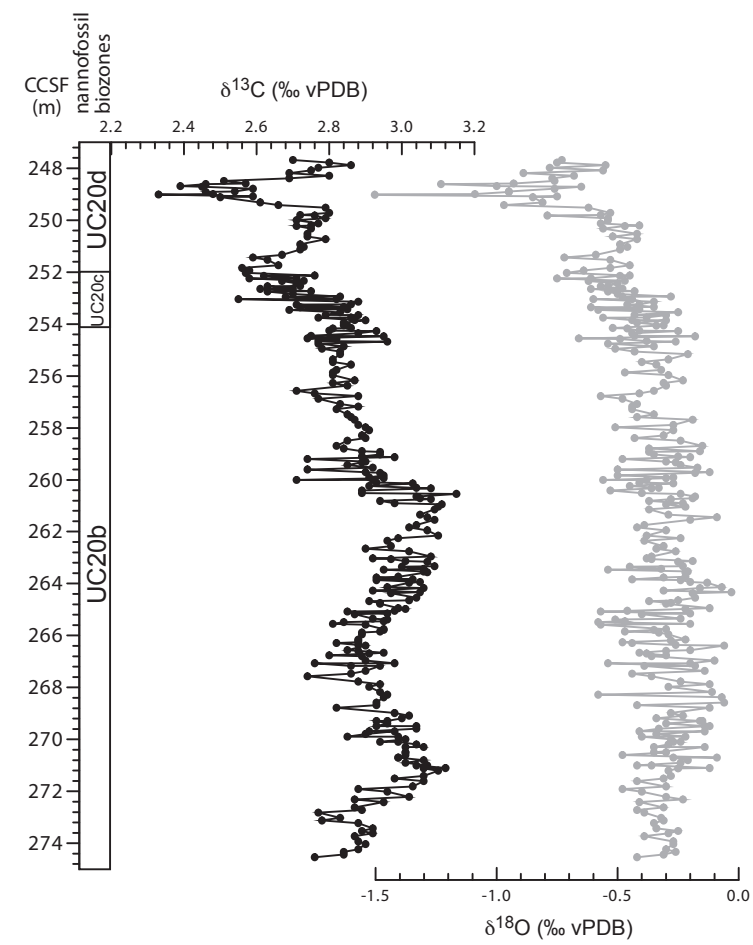

Figure 2: Bulk-carbonate carbon and oxygen isotope data from IODP Site U1403 (IODP Expedition 342) against CCSF and relative to shipboard calcareous nannofossil biostratigraphy (Norris et al., 2014). 
Clim. Past Discuss., doi:10.5194/cp-2016-51, 2016

Manuscript under review for journal Clim. Past

Published: 18 May 2016

(c) Author(s) 2016. CC-BY 3.0 License.

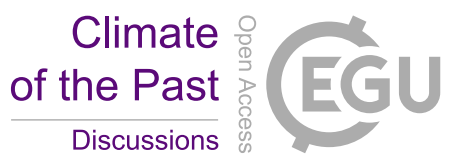

(c) (i)

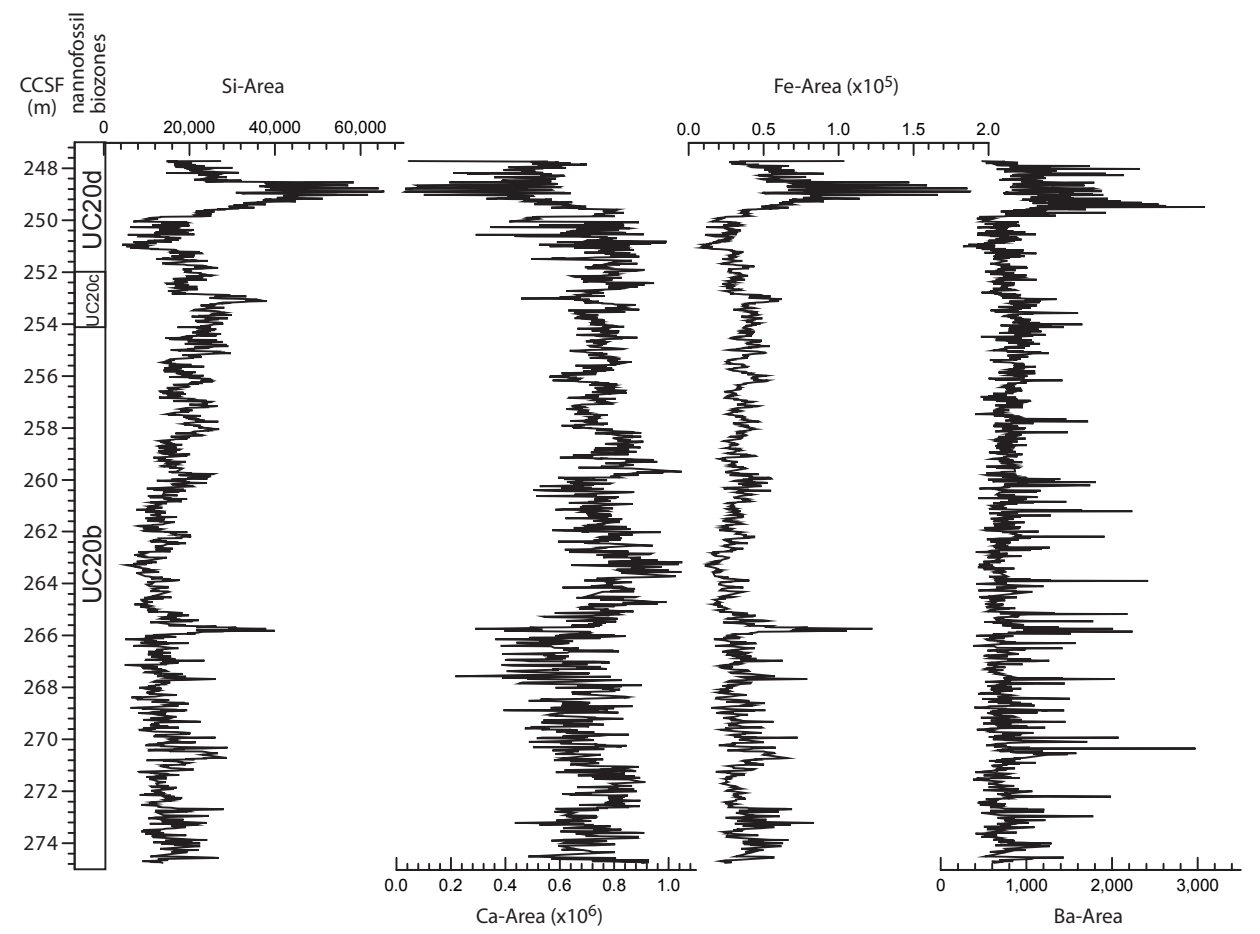

Figure 3: High-resolution XRF scanning silica, calcium, iron and barium elemental intensities from IODP Site U1403 (IODP

Expedition 342) against CCSF and relative to shipboard calcareous nannofossil biostratigraphy (Norris et al., 2014). 
Clim. Past Discuss., doi:10.5194/cp-2016-51, 2016

Manuscript under review for journal Clim. Past

Published: 18 May 2016

(c) Author(s) 2016. CC-BY 3.0 License.

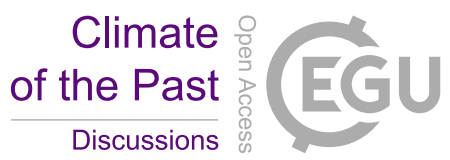

(c) (i)

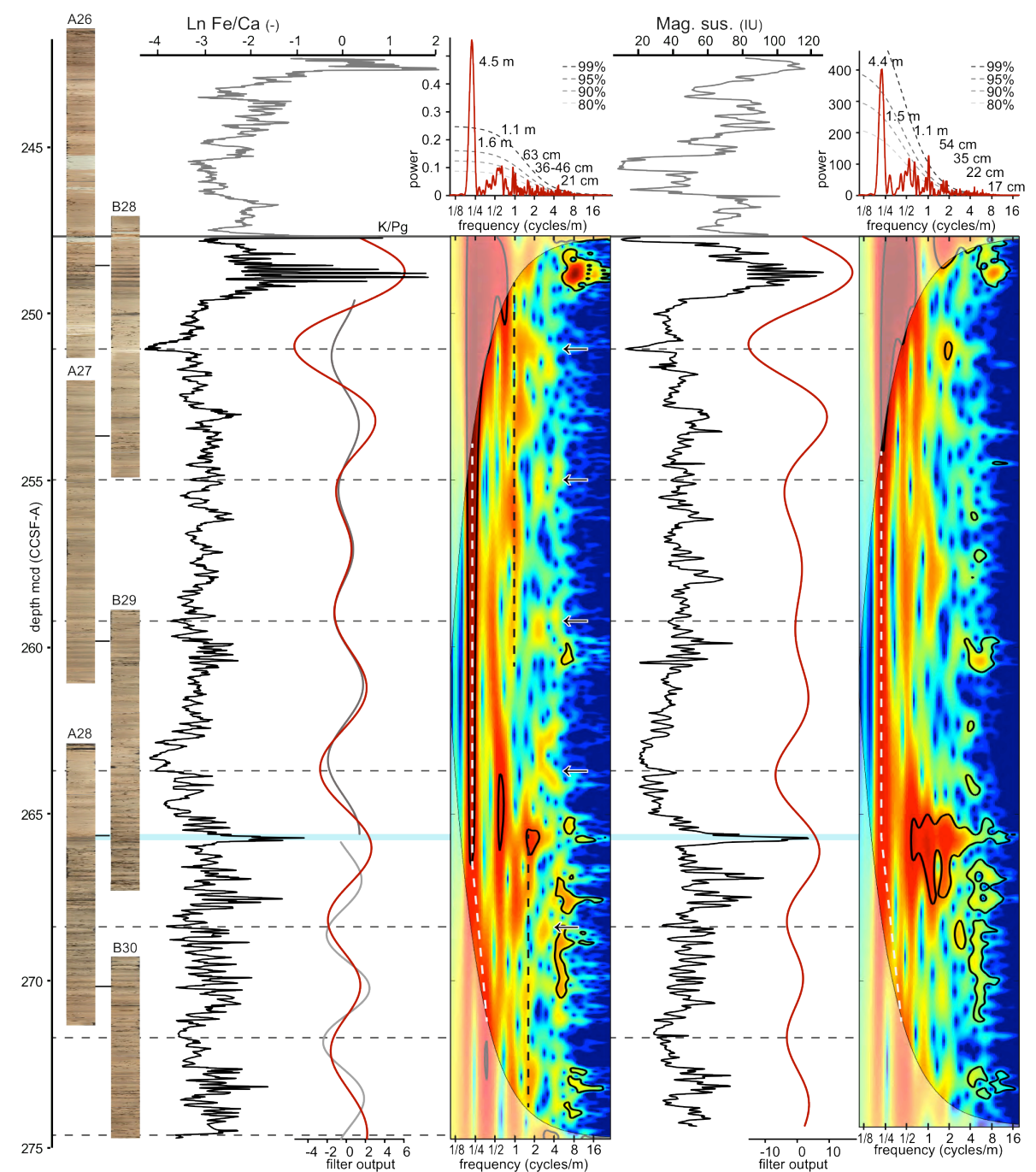

Figure 4: Time series analyses of the natural logarithm of the ratio of $\mathrm{Fe}$ and $\mathrm{Ca}$ counts (ln $\mathrm{Fe} / \mathrm{Ca}$ ), obtained by $\mathrm{XRF}$ scanning of the Maastrichtian interval of U1403, and the magnetic susceptibility (shipboard data, instrument units). From left to right: joined core photographs with splice tiepoints (black bars), ln $\mathrm{Fe} / \mathrm{Ca}$ (left) and magnetic susceptibility (right) in the depth domain, flanked by band-pass filters, wavelet analyses and Redfit power spectra. For $\ln \mathrm{Fe} / \mathrm{Ca}$, the band-pass filters over the whole record is indicated in red and centered at $4.5 \mathrm{~m}$ (bandwidth 3.4-6.8 m). The band-pass filters over the partial records are centered at $4.2 \mathrm{~m}$ (bandwidth 3.1-6.3 m) for the upper part (dark grey) and 3.3 m (bandwidth 2.5-5.0 m) for the lower part (light grey). For magnetic susceptibility, the band-pass filter over the whole record, in dark red, is centered at 4.4 $\mathrm{m}$ (bandwidth 3.3-6.7 m). Blue shading indicates the interval between 265.60 and $265.85 \mathrm{~m} \mathrm{CCSF}$, where the records are cut. Black arrows within the wavelet analyses panel of $\ln \mathrm{Fe} / \mathrm{Ca}$ indicate periodic amplitude amplifications in the frequency band of 36-46 cm. Dark grey dashed lines indicate the stratigraphic positions of minima in the $\mathrm{ln} \mathrm{Fe} / \mathrm{Ca}$ record that occur within minima in the band-pass filters, and are used as tie-points for the age model (Table 2). 
Clim. Past Discuss., doi:10.5194/cp-2016-51, 2016

Manuscript under review for journal Clim. Past

Published: 18 May 2016

(c) Author(s) 2016. CC-BY 3.0 License.

Climate

Discussions

(c) (i)
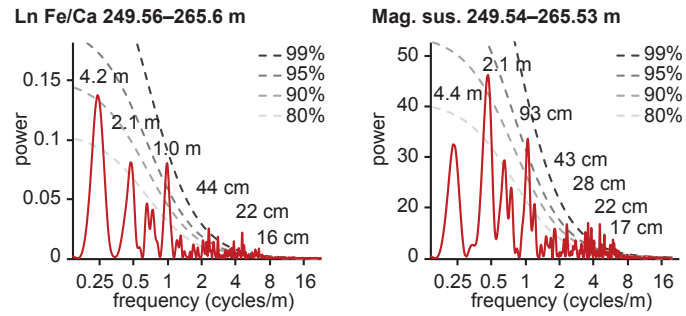

Ln Fe/Ca 265.85-274.73 m

Mag. sus. 265.97-274.37 m
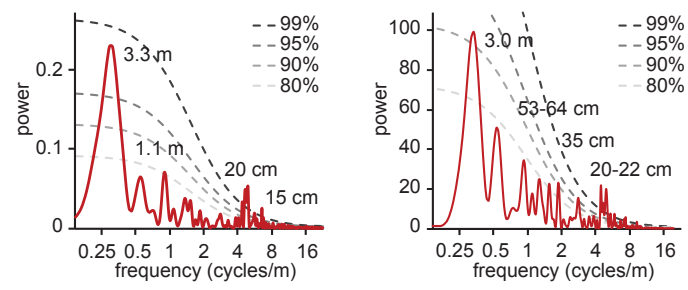

Ln Fe/Ca 249.56-274.73 m

Mag. sus. 249.54-274.37 m
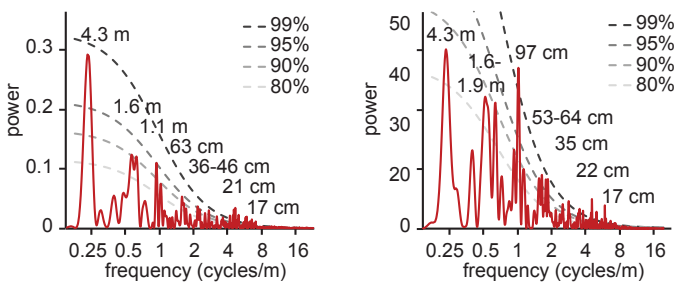

Figure 5: Redfit power spectra of the partial records of $\ln \mathrm{Fe} / \mathrm{Ca}$ (left) and magnetic susceptibility (right). Top panel: the upper interval between the peak at $265.6 \mathrm{~m}$ and the variability below the $\mathrm{K} / \mathrm{Pg}$ boundary, starting at $249.56 \mathrm{~m}$; middle panel:

the lower interval from the peak at $265.85 \mathrm{~m}$ downwards; bottom panel: the interval from the main variability below the

$\mathrm{K} / \mathrm{Pg}$, starting at $249.56 \mathrm{~m}$, downwards. 
Clim. Past Discuss., doi:10.5194/cp-2016-51, 2016

Manuscript under review for journal Clim. Past

Published: 18 May 2016

(c) Author(s) 2016. CC-BY 3.0 License.

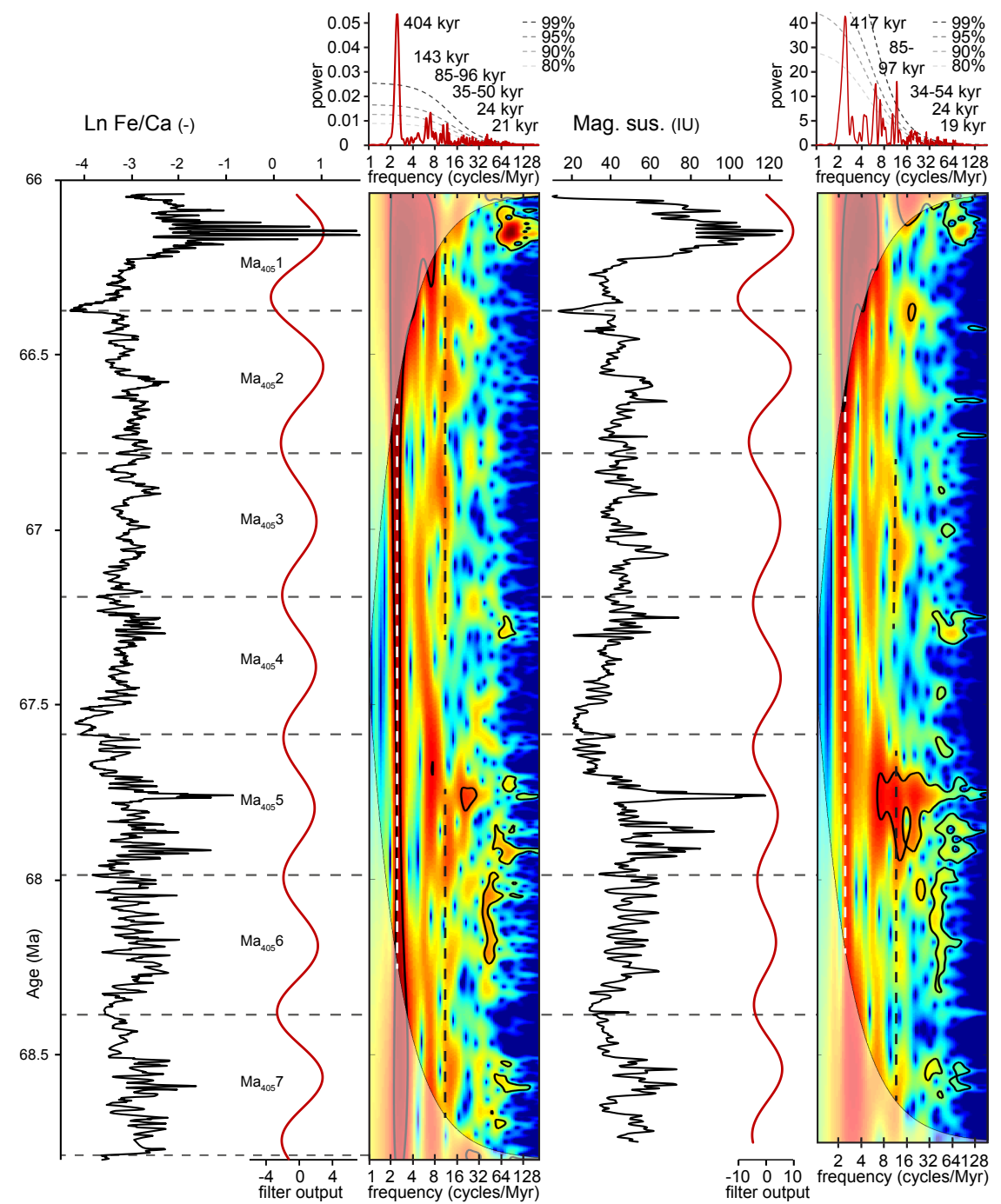

Figure 6: Time series analyses of the $\ln \mathrm{Fe} / \mathrm{Ca}$ and magnetic susceptibility records calibrated to the 405-kyr component of eccentricity. Left: the $\mathrm{ln} \mathrm{Fe} / \mathrm{Ca}$ record in the time domain, flanked by a band-pass filter centered at 404 kyr (bandwidth 302 $612 \mathrm{kyr}$ ), and wavelet analyses, topped by a Redfit power spectrum. The curved grayscale lines indicate the $99 \%, 95 \%, 90 \%$

and $80 \%$ confidence levels, from the uppermost to the lowermost, respectively. Right: idem for the magnetic susceptibility record, with a band-pass filter centered at $417 \mathrm{kyr}$ (bandwidth 313-627 kyr). Dark grey dashed lines indicate the positions of minima in the $\ln \mathrm{Fe} / \mathrm{Ca}$ record that are used as tie-points in the age model. $\mathrm{Ma}_{405}$ numbers indicate the 405 -kyr cycle from the $\mathrm{K} / \mathrm{Pg}$ boundary back in time. 
Clim. Past Discuss., doi:10.5194/cp-2016-51, 2016

Manuscript under review for journal Clim. Past

Published: 18 May 2016

(c) Author(s) 2016. CC-BY 3.0 License.
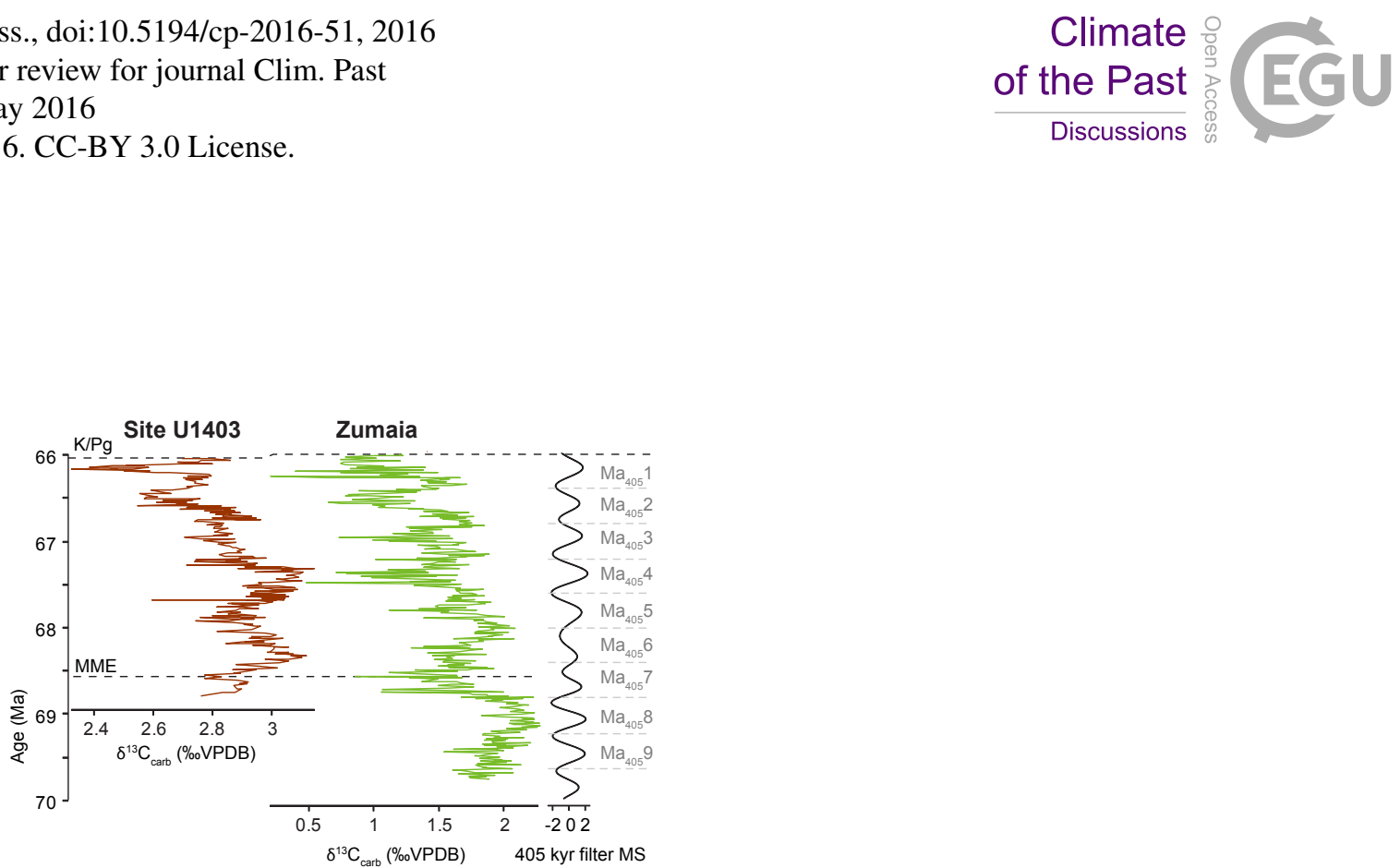

Figure 7: Correlation of carbon isotope values from IODP Site U1403 with the $\mathrm{d}^{13} \mathrm{C}$ record of the Zumaia section (Batenburg et al., 2012). Both records plotted against the age models derived from the independently established cyclostratigraphic interpretations (this study and Batenburg et al., 2014). Black stippled lines indicate correlation points of the K/Pg boundary and the MME. 